\title{
Politologia
}

\section{The basis of state image formation in international communication, as exemplified by the Republic of Belarus}

\author{
Elena Zhminko \\ Independent Researcher \\ Brest, Belarus
}

\section{Abstract}

In the modern world, the formation of a state's image, which is one of its main resources, largely depends on the state's participation in international communication processes. Whether the formation of the image will be successful is largely determined by three factors: the clarity and intelligibility of its identification, both for its citizens and the international community; the compliance of the legal framework in the field of information relations with international standards; and the structuring of the information policy according to the principles of two-way communication, including openness and free access to information. The political authorities of the Republic of Belarus, relying on the concept of ideologization, treat the global exchange of information as a threat to the legitimacy of its power and try to cultivate absolute control over the communication and information processes, paradoxically making it impossible to implement the tasks set by themselves in this area.

\section{Key words}

state image, international communication, state international identity, image of the Republic of Belarus

\section{Introduction}

he communication and information process have the potential
to create balanced attitudes in relations between actors on the international arena, which is becoming ever more often a counterbalance to military force. The opening of international communication to other participants of the process increases the role of other actors in 
the formation of a state's image. Nation states continue to play a decisive role in this process, because they have the greatest impact on the basic elements of the structure of the state's image, affecting the process of its positioning and communication on the international arena. An analysis of the contemporary international communication system highlights its new characteristics, such as polycentrism and networking, confirming the fact that the number of communication participants is increasing, while at the same time there is a differentiation of their roles in the communication processes and a varying intensity of connections and durability of contacts between them. The contemporary structure of international communication emphasizes the role of two-way communication, that is, a withdrawal from the outdated form of one-way messages in favour of an exchange of information. This constitutes the basis for the construction of the communication space.

Developing the structure of a state's image is not easy, as evidenced by the number of models created so far. At the same time, changes in the structure of communication across borders also affect the changes that appear in the image structure of participants in a given process. Among the many tasks arising at the intersection of a state's image and international communication there are three in which the state has the most influence, and these constitute both the basis for creating the conceptual framework of a state's international communication strategy and determining its image in this process. These are: the international identity of the state; the law in the area of communication and information; and the state's information / communication policy. These three components constitute a permanent structure defining a state's image in international communication its essence, its communication in relations with other participants of the communication process across national borders, and the way in which this communication works and principles according to which relations based on it are built.

The aim of this article is to analyse the basic elements of the image of the Republic of Belarus which affect the state's participation in the processes of international communication. The first part of the article 
presents the results of the analysis of contemporary directions in academic considerations on the state of the identity of the Republic of Belarus in the context of its historical and social conditions. In this part I point out the national specificity of the Belarusian identity formation and the role of political power in this process. The second part of the article is based on existing legal regulations in the Republic and an assessment of their implementation by the civil society, both inside the country and abroad. The third part focuses on the state's information policy in the area of forming its image and the role that state institutions and civil society play in this process. The article concludes with an assessment of the prospects for image formation of the Republic of Belarus in international communication.

\section{The international identity of the Republic of Belarus}

The research into the international identity of the Republic of Belarus can be considered a matter of complexity for several reasons:

1. Belarus has been its own state less than one hundred years. While the Belarusian people became independent in 1917 following the rapid socio-political changes in Russia, those changes resulted in the emergence of the Belarusian Soviet Socialist Republic as part of the Soviet Union;

2. as an independent state it has existed for only 27 years (Belarus gained sovereignty in 1991);

3. the lack of homogeneity and its fragmentary nature, derived from the specifics of forming the identification processes, run in two general directions at the same time: official (political-state) and unofficial (socio-cultural);

4. Belarus, like many other states, is undergoing a so-called 'identity crisis', arising from the fact that globalization trends tend to blur national identities and, consequently, require their reidentification.

In this situation, it is not surprising that the problem of Belarus's national identity and its place in the geopolitical structure of the world 
throughout the Republic's sovereignty is at the centre of interest of researchers - especially those who are independent from the official state mainstream - and is based on power institutions and the pursuit of policies. Trends in the academic and civic discussion of elites, focused on the issue of Belarus's identity and its representation on the international arena, reflect the specificity of identity formation in Belarus and confirm the thesis about the lack of unanimity on the basic elements of national identity, such as language, culture, or national symbols (Akudovich 2004; Akudovich 2007; Babkoŭ 2003: 64-77; Babkoŭ 2005: 136-165; Bulhakaŭ 2003: 328-351; Bulgakov 2006; Ekadumov 1999: 199-204; Kazakevich 2004: 51-84; Kazakevich 2010: 21-40; Rudkoŭski 2006: 62-68; Rudkoŭski 2007). It should not come as a surprise that Belarus is in the process of identity formation; on one hand because the process started relatively recently in comparison with other European nations, and on the other hand because identity itself is a construct that 'becomes', and it is not 'given' once and for all as an inborn trait. Therefore, the identity of Belarus should be considered to be a process, i.e. not static, which some analyses do not take into account, thus missing the connection with social reality and condemning their projects to remain at the level of the world of ideas, often not having a practical application.

Most of the directions of academic research reflect, in one way or another, the characteristics of the fragmentariness of the ethnic and cultural areas of Belarusian identity (Vodolazhskaia 2010; Prokopiuk 2013: 118-127). Researchers take note of an overlapping borderline category as a permanent element of Belarus's national identity and a unique geopolitical feature of the country. There are still different approaches among researchers towards language as a basic form of identification for the nation, but the contemporary assessment of the identity processes taking place in the Republic makes everybody aware of the inability to implement a 'revival' project of Belarusian identity based on the formation of a monolithic construct.

Both official and independent sociological studies point to the transformative nature of Belarusians' identity: on the one hand 
the observed differences between the approach to the topic under study among representatives of different age groups are an objective reflection of the historical and social processes which have occurred and are occurring on the territory of Belarus, including the fact of the young statehood of the Republic. On the other hand, Belarusians' poor identification with the categories of culture and religion which are typical for other European countries attest to the impossibility of looking into Belarusian identity in line with the existing traditional theoretical models (Shestakova 2009; Naumenko 2008: 111-133; Naumenko 2012). Unfortunately, the studies most often do not include a political factor, which it seems could explain the specifics of identity formation at Belarus's contemporary stage. Nevertheless, in analysing the results of these studies in the context of the political and social processes of the last fifty-sixty years it can be concluded that in most cases the state has taken responsibility for the identity structuring and has tried to form this identity from above (including both the state as a Soviet Republic and as a sovereign Belarus).

In Andrei Kazakevich's view (Kazakevich 2010: 21-40) ${ }^{1}$, the possibility to form a national identity and, consequently, the state image, by the state-political concept is reduced by: a lack of defining the structure of national identity by the intellectual elites of the country (Bulgakov (ed.) 2006); mutually exclusive assumptions of different concepts that divide Belarusians into almost opposing camps; and globalism, which prevents the implementation of a traditional nation-building project and forces national identities toward reidentification and the incorporation of a civilization component into its structure, i.e. general values professed and proclaimed by international organizations (such as, for example, the United Nations), on the basis of which the state and the nation are integrated into the international space. This does

1 The basis of the state-political concept is understanding the nation as citizens (residents) of the Republic of Belarus, which is related to the Belarusian ideology project, implemented since 2003 on the basis of a state order (which is formally similar to 'pure' civic nationalism, and its cultural neutrality consists of the important role of the Russian context and distancing itself from the Belarusian culture). 
not mean that civil society cannot, as a part of its activities, participate in the process of forming and redefining the national identity, but that its opportunities are limited because it does not have access to two other basic elements - legislation and government policy. As it has been mentioned, this concept is characterized by flexibility, based on adaptation to the current historical and political situation, which gives the opportunity to search for other forms of influence on the identity process by, above all, the intellectual elites of the state. Nevertheless, both the directions of the studies on the identity of Belarus and the established academic concepts, as well as surveys of civil society leaders (Bulgakov (ed.) 2006), indicate that state authorities have the greatest influence on the identity of the Republic of Belarus - its formation and representation.

State authorities form and implement activities in the area of the state's identity within the ideology of the Belarusian state. The Constitution of the Republic of Belarus (I994) is considered to be the legal basis for this process. The Administration of the President of the Republic of Belarus is responsible for guaranteeing the implementation of the state ideology. State ideology is understood as a 'system of fundamental principles and orientations, defining the strategy of state development based on civic choice and reaching a consensus on the fundamental principles and goals of development. It is socio-political oriented because it explains the mutual bonds and mutual responsibility of the citizen and the state' (Nikitenko (ed.) 2009: 89). This means also with respect to each other, a condition that forms the basis of this relationship. The main directions of the state ideology of Belarusian society include: the substantiation of the Belarusian development model and the place of Belarus in contemporary civilization; developing the idea of the Belarusian people as a community within the sovereign Belarusian state; the historical continuity of societal development; and defining the conceptual positions of Belarussian history (Rubinov 2006).

Attempts to analyse the content of the ideological documents of the Belarusian state show a quite general and fuzzy treatment of the developmental directions of the Republic, especially in the area of culture (Batalko, Pashkevich 2009; Iankovskaia 2009; 
Kniazev, Reshetnikov (eds.) 2004). This leaves a loophole for introducing changes in the principles of the ideology. However, observation of the trends in the implementation of its principles allows us to state that the introduced changes indicate only its top-down development, based on adjusting to temporary political and economic needs. Invariably paternalism, cultivating homo sovieticus, and ideological stability have been considered as the main basis of identity. The authorities under the influence to a greater extent of the situation in international relations - gradually broadened the scope of the notion of state identity. Especially from the beginning of the Russian-Ukrainian conflict in 20 I4 the authorities, positioning Belarus in the international space, have been focusing on emphasizing its independence as well as its role in establishing peace in the region. In recent years Belarus has taken a multi-vector direction in international relations, consisting of balancing and taking a neutral position. The conflict situation between Belarus's biggest neighbours influenced the introduction of 'soft' Belarusianisation in the public space (Rudkouski 20I7). This meant a less aggressive attitude toward the national symbols of the pre-Soviet period and the expression of opposition towards actions or statements offending the Belarusian language and undermining the independence of Belarus. This has led to the appearance in the public discourse of historical information from before World War II, which up until now has been a pillar of the ideological narrative. It is difficult to assess whether this two-year trend will be consolidated and whether it has chances for further development. To a large extent it depends on the economic situation of Belarus and international relations in the region.

The media play a special role in the activities of state authorities in their process of ideologizing society, because the essence of the process has always been rooted in the opinion of the masses vis-à-vis specific convictions, beliefs and ideas. The Belarusian case is not an exception in this regard, although the use of ideological indoctrination is explained by the necessity of creating an independent state in the conditions of globalization, which requires an intensive influence on information and the unification of identification. 
The top-down control automatically undermines the authenticity of transmitted information and prevents a two-way communication process, because it would call into question the media content, which then could not effectively influence public opinion. In the absence of competitive content (or at least limited access to it), ideologization has a greater chance of becoming rooted in the national consciousness, which is confirmed to some extent by sociological research. What's more, the conducted studies from the period of the Belarus-Russian information war in 2009-20I0, as well as from the conflict period in Ukraine, have confirmed that the geopolitical mood of the Belarusians depends on the direction of information (Shraibman 2017). It should be noted that the principles of ideologization are not consistent with the basic features of contemporary international communication. In the case of ideologization, communication concentrates around one centre (the rest are treated as peripheries), is subordinated to a vertical structure, forms a network (but one strictly controlled by the centre), and does not assume openness to other content, especially content criticizing the ideological premises.

It seems that even the Belarusian authorities have noticed the shortcomings of the ideology introduced so far with regard to the contemporary structure of international communication and the dynamically changing political situation in the international space. This has led to the introduction of changes and extension of the concept of state ideology. Civil society, however, is not yet ready to propose alternatives to state ideology. Like the state authorities, it must update the directions of its activities taking into account the social mood and the needs of contemporary Belarussians.

\section{The law governing information and communication in the Republic of Belarus}

Owing to its membership in international organizations, the Republic of Belarus is obliged to form its internal law, including communication and information law, in accordance with international law. In addition 
to the international documents, the legal basis for information and communication are the Constitution of the Republic of Belarus, the laws, decrees and ordinances of the President of the Republic of Belarus, legally binding resolutions and regulations of the Council of Ministers of the Republic of Belarus, as well as national programs and plans regarding the implementation of international legal norms.

Belarus's information policy is regulated by two state authorities the Ministry of Information of the Republic of Belarus and the Ministry of Communication and Informatization of the Republic of Belarus. The Law of Io November 2008 'On Information, Informatization and Protection of Information' (2008) confirms the fundamental rights of individuals and the mass media, but with a clause permitting possible restrictions in order to ensure state security (Arts. 3-7).

The Ministry of Foreign Affairs of the Republic of Belarus regulates the foreign information policy on the basis of the Law of the Republic of Belarus, dated I4 November 2005, No. 60-3 'Concerning approval of the main directions of domestic and foreign policy of the Republic of Belarus'. This Law assumes the taking of steps towards the integration of the state into a global information space on the basis of mutually beneficial cooperation in the field of information and computerization (Art. 34). The same article of the Law mentions two areas that should be taken into account from the point of view of formation of a positive image of the state on the international arena - sports and participation in international sports events, as well as tourism and the promotion of a national tourist product on the foreign market. It should be noted that the area of sports and sports achievements is considered as a space for building the international authority of the Republic of Belarus, while the forming of an attractive image is based primarily on the development of tourism in the region.

The activities of mass media and international cooperation in this area are regulated by the Law of the Republic of Belarus dated I7 July 2008 No. 427-3 'On mass media', treating the media as participants in international cooperation based on international agreements of the Republic of Belarus (Art. 45). Like the Constitution of the Republic of Belarus 
(2004: Arts. 33-34), this law also emphasizes the inadmissibility of media monopolization, including by bodies of state power (Art. 6), and as well prohibits censorship or other illegal restrictions on freedom of expression (Art. 7). However, the dissemination of foreign mass media on the territory of the Republic is possible only after receiving a permit issued by the appropriate national public administration body in the area of mass information (Art. I7).

Amendments to this law entered into force from Ist of July 20I5. At the moment the law includes regulations on restricting access to mass media disseminated via the Internet (Art. 5I). However, there is a lack of precise information with respect to which cases possible restrictions may apply, or what may be the subject of warnings from the authorities verifying media content. The introduced changes equated the Internet resources with the mass media in terms of their duties and rights (with no registration duty).

Three years after the introduction of these changes, the Belarusian authorities are still tightening the law in the area of freedom of speech and the media. On June I4, 2018 further changes were adopted to the above-mentioned laws aimed, according to the legislator, to fight 'fake news' and to take care of the information security of the state (Act of I4 June 2018 'On introducing changes and amendments to some laws of the Republic of Belarus'). The changes widen the authorities' possibilities to block websites and introduce criminal liability with respect to persons dealing in the dissemination of false information on the Internet. What's more, this also includes comments on social networks. In fact, the amendments may lead to an even greater restriction of freedom of expression and information in Belarus (Tut.by - news service, 20I8, 'Izmeneniia v zakon o SMI'; Radio Svoboda - news service, 20I8, 'Popravki v zakon o SMI v Belorussii vyzvali kritiku').

The analysis of these and other key normative instruments (e.g. Decree of the President of the Republic of Belarus of the $9^{\text {th }}$ November 2010 No. 575 'On approval of the National Security Concept of the Republic of Belarus') indicates two vectors for forming legal regulations: on the one hand, the state wants to be perceived as an independent European 
state with a high level of democratic development (Art. 9, 23), ready to be included in the common information space (Aleksandrovich (ed.) 2004); while on the other the law emphasises the existing threats caused by processes of globalization, and thus introduces legal regulations consisting of increasing control over and restrictions on information flows, in particular through mass media (Arts. 5, 42). The result of the obvious contradiction of the introduced legal regulations, their lack of specification, and the broad interpretation of threats to the information security of the state is that it creates possibilities of abuse from the side of the state authorities in terms of blocking and / or limiting access to information.

The role of state ideology in affecting the formulation of legal regulations in the area of information and communication is palpable. According to the 'National strategy for sustainable socio-economic development of the Republic of Belarus for the period up to 2020' (Aleksandrovich (ed.) 2004), a fundamental role is foreseen for, inter alia, ideological protection, which means making every citizen aware of the ideas and principles of constant development, which in turn will serve to instil new values in the national consciousness; and mass media should consider this as a priority in their activities (Aleksandrovich (ed.) 2004: I4). It is obvious that all other views and opinions differing from the proposed ideological interpretation may be considered as threatening the state's information security and incompatible with the information policy of the state.

Thus, the existence of legal norms does not in fact assume effectiveness in their implementation, which depends on the efficacy of the mechanisms of applying international law included in national legislation. According to the regulations of international organizations of which the Republic of Belarus is a member, the state must report cyclically on its achievements and the results of operations in a specific area. The latest data on information and communication issues are included in the National Report for the Universal Periodic Review of human rights of 2015 (Natsional'nyi doklad k universal'nomu periodicheskomu obzoru (vtoroi tsikl), Respublika Belarus'), prepared 
for the United Nations ${ }^{2}$. This report states that the analysis of national legislation carried out in 2OII-2OI3 showed no contradiction between national legislation and international agreements, with the possibility of further harmonization of legal norms (Art. I6). However, apart from pointing out the improvements contained in the Law 'On mass media', even the specialized paragraph $\mathrm{P}$ of the Report, which concerned the verification of activities under the law of freedom of opinion, peaceful assembly, and association, does not contain any information on the freedom of information and communication.

The UN Special Rapporteur on Belarus, Miklós Haraszti, referred extensively to the above-mentioned Report when presenting the results of his analysis on October 29, 20I5 to the UN General Assembly. The Special Rapporteur's report focuses on the area of freedom of expression in the Republic of Belarus and gives a clearly negative evaluation of the activities carried out, including legislative ones, thus underlining the lack of implementation of constitutional principles and international arrangements by the Republic of Belarus. Most of the legal regulations regarding mass media have been criticized. The main complaints of the Special Rapporteur concerned the following problems:

- the established system of mass media management suppressed the implementation of the right to freedom of expression and information;

- the lack of media pluralism, with the state acting as a direct regulator of all types of media;

- $\quad$ additions to the Law 'On mass media' from 20I4 allow for state control of statements on the Internet;

- the independence of the media is limited by the obligation to register and the need to obtain permission from the authorities, as well as the unclear rules for the liquidation of a license;

- the lack of clarity concerning the basis for recognizing media statements as threatening state interests or as insults;

2 The report was presented to the UN Human Rights Council by a Belarusian delegation headed by Deputy Foreign Minister RB Valentin Rybakov on 4 May 2015. 
- the existence of persecution of journalists, as well as preventing or restricting their work (Report of the UN Special Rapporteur on the situation of human rights in Belarus, 2015: 8-20).

In the subsequent Report of I5 May 20I8, the UN Special Rapporteur also recognized that the proposed amendments to the Law 'On mass media' would lead to an even greater restriction of the freedom of speech and information in Belarus: 'The amendments, if adopted, would perfect the systemic curtailing of freedom of expression, and allow the authorities to legally block the only remaining public space for free debate, the Internet' (2015: 6). Analyses and monitoring by independent civil society organizations and institutions, both in the Republic of Belarus and abroad, confirm the position of the UN Special Rapporteur. According to the international data of the nongovernmental organization Reporters Without Borders, in its annual publication of the international media freedom ranking Belarus was on $155^{\text {th }}$ place among I80 countries (20I8 World Press Freedom Index).

An opinion poll on the current issue of the "free Internet”, based on the data of the Legal Transformation Center „Lawtrend” and the company Novak, shows that $60 \%$ of respondents encountered violations of their rights with respect to 'freedom of the Internet' and $23 \%$ experienced them personally (Lawtrend 2015). According to the respondents, the right to access Internet resources is the most often violated. According to the Freedom House Report 'Freedom on the Net 20I7', Belarus is one of the leading countries abusing and violating user rights and introducing limits on content.

According to official data the number of Internet users whose aim is to obtain information - including news about and from the country and the world - is constantly increasing (in 2009 the Internet as a source of information was indicated by $24.2 \%$ of respondents, and in $20 \mathrm{I} 4$ by $53 \%$ ). It shows that today the Internet is a more desirable source of information than the press (Dashkevich 20I4: I6). A comparison of the results obtained by independent research centres with official information (or lack thereof) indicates that there are undoubtedly difficulties in managing information and communication flows. 
The too general wording in legislative documents, or the introduction of mechanisms that in fact prevent the implementation of international legal arrangements, create a major dissonance between international obligations on paper and their implementation in practice. Without a full reconciliation of Belarus's internal legislation with the binding international standards resulting from its membership in international organizations, Belarus will not be able to achieve its strategic goals, including the engagement of the state in the global information and communication space. By not taking into account the recommendations for improving the situation with respect to information and communication flows and the transition to a two-way communication model with recipients who should be included in the communication process and become full participants, Belarus hinders the implementation of state's positioning in the international communication space, as neither state institutions nor other communication participants have the basic tools to fully participate in this process. This puts the state at a disadvantage from the point of view of forming a positive image abroad, and weakens the actions it undertakes.

\section{The image dimension of the information policy of the Republic of Belarus ${ }^{3}$}

The assumption of Belarusian academics that the information policy of the Republic of Belarus is built on the visible principle of internal and external divisions becomes the basis for studies on the state's image. Its structure is considered traditionally as being in correlation with the main directions of the state's functioning as such - the internal image of the state is identified with the internal policy of the state, and the foreign image - with the state's foreign policy (Gorskii 2010: 91).

3 When speaking of the image dimension of information policy, I mean those aspects that affect the formation of the state's image in information processes, in particular those of an international character. Here the term 'information policy' was used because in the Republic of Belarus the concept of communication policy has not yet been formulated. 
The analysis of legal documents indicates that the image dimension of information policy is dealt with by the Ministry of Foreign Affairs of the Republic of Belarus, which would confirm the thesis concerning the systematic division of the problem and point to the need for a structural solution. Therefore, it can be said that Belarus's foreign information policy is formed on the basis of the foreign policy of the state and is considered as a part of it. The foreign policy goals of the state are the goals of the information policy directed beyond state borders.

The claims included in legal documents concretize the most important areas of information policy directed abroad within the context of its image dimension, namely:

- $\quad$ supporting the integration of Belarus with the global information space;

- using information technology and information exchange for the country's economic development;

- forming a positive image of Belarus through sporting achievements and participation in international sports events;

- building the authority of the state through the promotion of Belarus as a tourist destination;

- $\quad$ promotion of the Republic of Belarus as a democratic state based on the rule of law, as an equal, responsible, and predictable partner, and as an ally of international and regional security;

- $\quad$ informing the international community about the state, its position with respect to the most important international problems, its external political initiatives, and the achievements of Belarusian culture and science.

The Belarusian foreign information policy focuses on three geographical spheres: Euro-Asian (including, in particular, Russia); European (especially with neighbouring countries); and global (with partner countries and the United States of America) (The Ministry of Foreign Affairs of the Republic of Belarus, 'Priorities of the foreign policy of the Republic of Belarus'), and three thematic areas: the economy (including investments), tourism, sport. Structural and functional analyses make it possible to determine the division of responsibilities 
of state administration bodies and other departmental institutions in this area, and help to identify the decision centres in a given structure. In general terms, five entities and groups of entities that influence the foreign information policy of the state, including in the areas of formulating and the positioning of the state image, can be distinguished. These are: the President of the Republic of Belarus; the Administration of the President and subordinated institutions; the Ministry of Foreign Affairs of the Republic of Belarus and diplomatic missions abroad; other ministries and departments; institutions specialized in information and communication and the state media; and civil society and the independent media. Below I indicate only the most important tasks and functions of these actors from the point of view of the topic under discussion.

Due to the fact that the political regime in Belarus in many matters is guided by the principles of authoritarianism (Usow 2016: 13-28), the President's office and all information activities connected with it have a special significance for the formation of the information policy, and its image dimension in particular. The President's speeches and statements are treated as a reference point, as guidelines, and as a plan to be implemented in the area of the state's image, its content, priorities in the structure, and forms. However, the Administration of the President of the Republic of Belarus is the main institution securing the introduction of the ideology of the Belarusian state and the coordination of activities in this area with foreign policy.

The specialized activities of the Ministry of Foreign Affairs of the Republic of Belarus in terms of state promotion and forming its positive image abroad are focused on providing information and propaganda concerning the foreign political and economic activities of the Republic of Belarus, and on offering support in attracting foreign investments that contribute to the country's economy, as well as on building a positive investment image of the country abroad and increasing its position in international investment rankings (The Decision of the Council of Ministers of the Republic of Belarus of 31 June 2006 No. 878 'Questions of the Ministry of Foreign Affairs of the Republic 
of Belarus', Art. 6.2, 6.30). It is worth noting that the press services of embassies and diplomatic representatives of the Republic of Belarus are also involved in informing the international community about the situation in the Republic of Belarus, in accordance with the rules set by state bodies in the country. In most cases websites are the main source of information, containing basic data about Belarus, opportunities for developing economic cooperation, tourism in the country, and information and links to state-owned mass media. One of such internet portals is Belarus.Facts (www.belarusfacts.by), which contains links to all diplomatic representations of the Republic, as well as information about the state - its political system, economy and business, culture, tourism and sport, and news that may be of interest in the context of visiting Belarus or learning about its achievements.

Other ministries and institutions build their strategies for their activities in strict dependence on the directions provided by the President of the country or his administration. The Ministry of Information of the Republic of Belarus implements state policy in the area of mass information by formulating its culture and strengthening its legal bases. With respect to activities strictly related to international communication, the Ministry of Information of the Republic of Belarus is responsible for the organization and development of international cooperation in the area entrusted to it (The Decision of the Council of Ministers of the Republic of Belarus of 26 October 2001 No. 1545 'On approval of the Regulations on the Ministry of Information of the Republic of Belarus', Art. 3). Given the ideological sensitivity of the information and communication area, it seems to be paradoxical that the Ministry possesses the power to exercise control over the mass media (including online media), while at the same time being charged with preventing illegal restrictions on the freedom of mass information, including preventing censorship.

As part of its competences, the Ministry of Information of the Republic of Belarus organizes international conferences on topics of importance from the ideological point of view, such as: the Belarusian International 
Media Forum 4 (in 2015 its 1oth edition was held under the slogan 'Partnership in the name of the future: the legacy of the Great Victory', dedicated to the 7oth anniversary of the state's victory in the Great Patriotic War, which constitutes one of the most important elements of the official state ideology, and thus - its formed identity, both national and international; or the international specialist exhibition 'Mass media in Belarus'. As an example of the implementation of the above function of the Ministry of Information of the Republic of Belarus in terms of the image dimension of information policy one may cite its activities in the preparation of a promotional video under the slogan 'Belarus: the place to live ${ }^{6}$ held in 2015.

The Ministry of Sport and Tourism has only limited tasks within the scope of its competences regarding Belarus image dimension, including the participation of national teams in international sports competitions, the development of international cooperation in the field of physical culture, sport and tourism, as well as representing the interests of the state in international sports organizations (via the conclusion of relevant agreements) (The Decision of the Council of Ministers of the Republic of Belarus of 29 June 2006 No. 963 'Questions of the Ministry of Sport and Tourism of the Republic of Belarus', Art. 5).

Despite the fact that the Regulations on the Ministry do not mention the role of the Ministry of Sport and Tourism in forming the state image, long-term programmes directly indicate this role. The state program for development of physical culture and sport in the Republic of Belarus for the years 2011-2015 was based on the assumption that sport is an effective instrument for strengthening the international image of the state, and the aim of such program was, among other

4 For more information, see http://www.mininform.gov.by/ru/mediaforum-ru/ (accessed January 2016).

5 For more information, see http://www.mininform.gov.by/ru/smi-v-bel-ru/ (accessed January 2016).

6 For more information, see http://www.belta.by/society/view/ananich-ideja-sozdanija-videorolika-belarus-strana-dlja-zhizni-poluchila-jarkoe-tvorcheskoe-175007-2015/ (accessed January 2016). 
things, to strengthen the Republic's position among the world-leaders in international sports (The Ministry of Sport and Tourism of the Republic of Belarus. 'State program for the development of physical culture and sports in the Republic of Belarus for 2011-2015', Sections 1, 5). The result of the program's implementation was to be the formation of a positive image of Belarus on the international sports arena (Section 6).

The website of the Ministry of Sport and Tourism of the Republic of Belarus promotes the state from the point of view of three categories: sport Belarus, tourist Belarus, and active Belarus - by providing the necessary information and a calendar of activities and undertakings for each annual period?. The promotional aspect is also provided by the website of the Belarusian National Tourist Agency www. belarustourism.by - an institution established to implement the program of the Ministry of Sport and Tourism in order to promote the state as an attractive tourist destination and shape a positive image of the state.

The Ministry of Culture of the Republic of Belarus is in charge of the implementation of state policy in the field of culture, covering the areas of culture, art, and the protection of historical and cultural heritage. Among its tasks, the international context is provided by the preservation of the national cultural heritage that is of significance for the entire Belarusian community, including in the context of its spiritual and moral improvement and - most importantly - in the context of the formation of national consciousness and developing cooperation with other countries in the sphere of culture (The Decision of the Council of Ministers of the Republic of Belarus of 30 October 2001 No. 1558 'Questions of the Ministry of Culture of the Republic of Belarus', Art. 4.3, 4.8). The image dimension is visible in the Ministry of Culture of the Republic of Belarus's function of supporting the popularization of Belarusian culture and traditions abroad, including among the clusters of the Belarusian diaspora in other countries, the development of relations with cultural organizations of other countries, and support for cultural centres abroad.

7 For more information, see http://www.mst.by/en (accessed January 2016). 
As in the case of the Ministry of Sport and Tourism, the Decision of the Council of Ministers on the activities of the Ministry of Culture does not contain direct guidelines on the role of the ministry in forming the state image, including in international communications. The State Program 'Culture of Belarus' for the years 2011-2015 explicitly formulates its strategic goal as 'strengthening the positive cultural image of the country' (The Decision of the Council of Ministers of the Republic of Belarus of 26 December 2010 No. 1905 'On approval of the State program 'Culture of Belarus' for 2011-2015', Section 1). The program recognizes the role of Belarusian culture in formation of the international image of Belarus and declares its priority role in positioning the state, defining it as the most effective resource. The program categorises Belarus's reputation as a state with the large spiritual and moral potential of society and a high level of development of all forms of traditional and contemporary culture, which - according to the authors of the document - will strengthen the authority of the state as a good partner in other spheres of life, maintaining a high investment climate, the development of international tourism, and other processes (Section 2).

The Ministry of Economy of the Republic of Belarus is the body charged with implementing the entire spectrum of tasks within the national economy of the state. Although the Ministry of Economy documents do not mention either the role of information and communication or the state image, it implements both through its executive institutions, which propagate a whole set of initiatives that involve the state in international communications in the field of economic cooperation, investment, development, and state promotion. The main task of all these activities is to formulate and maintain an attractive investment image of Belarus and also to position the country as a profitable investment site.

Undoubtedly, the pro-state media play an important role in forming the state image and the participation of Belarus in the processes of international communication, which on the one hand has become an instrument of the state administration, and on the other hand influences the formation of policy and its implementation. Coordination 
of the work of the state mass media is carried out at the discretion of the Administration of the President of the Republic of Belarus, which, as already mentioned, is responsible for ideologizing and influences foreign policy and its priorities. According to one of the last reports of the Organization for Security and Cooperation in Europe (2015), about $67 \%$ of all registered mass media outlets in Belarus are private institutions (dissemination of printed media takes place through state channels, in most cases by subscription), with the exception of all nation-wide TV channels, which belong to the state. However, the presence of Belarusian TV channels in the communication space of other countries is not very noticeable. Nevertheless, the National State Radio and Television Broadcasting Company of the Republic of Belarus (NSRTBC) actively participate in processes affecting the positioning of the state image in international communication, e.g. through membership in international organizations and associations (for example, from 1993 the European Broadcasting Union ${ }^{8}$, and in 2003 it was accepted into the National Union of Television and Radio Broadcasters of Russia and the Commonwealth of Independent States) ${ }^{9}$. In order to develop international cooperation within the NSRTBC, an International Relations Directorate was appointed, coordinating the work of all company sub-units in the area of international cooperation ${ }^{10}$.

The civil society and independent media operate separately from the above-mentioned actors. The socio-political system of Belarus, considered by international opinion as non-democratic and thus an autocratic way of managing processes and relations within the social system based on the great importance of control by the state administration, has changed the role played by civil society and

8 For more information, see http://www3.ebu.ch/about/members (accessed January 2016).

9 For more information, see http://www.nat.ru/ (accessed January 2016).

10 For more information, see http://www.tvr.by/company/direktsiya-mezhdunarodnykh-svyazey520/direktsiya6726/ (accessed January 2016). 
independent media in the country. The structures of civil society in Belarus can be divided into two categories:

1. those identifying with the state: implementing state policy, including ideological, and functioning as government institutions and organizations;

2. those not identifying with the state: criticizing the governmental policy and the means of conducting it, and implementing alternative undertakings within the framework of information and communication, including the international framework.

The activity of the first group falls within the priorities and forms of action set by the government structures, which is why they are not analysed herein. However, attention should be paid to the largest event regarding the formation of the state image within the framework of cooperation between 'independent' institutions and state structures, which is the annual 'Image of the Republic of Belarus' Forum, organized since 2010 by the Strategic Development Centre in cooperation with the Ministry of Economy of the Republic of Belarus and other state institutions; as well as the website www.imagebelarus.by, created for highlighting the Forum's activities ${ }^{11}$. This project aims to create a platform for exchanging views on the international image of Belarus and to develop a strategy for building it for internal and external recipients.

The activities of the second group of institutions are very limited, because they do not have access to the state's institutional resources nor support from the state administration, including the local administration. The question that arises is to what extent they can affect the formation of information policy and Belarus's image dimension in international communication. Such an impact is possible only under conditions of open dialogue and the development of a system of social consultations based on democratic principles, and joint works on the problem, especially when it concerns topics directly related to the perception

11 For more information, see http://www.imagebelarus.by/o-prokte (accessed January 2016). 
of oneself as part of a nation and the formation of identity. This approach triggers the process of seeking alternative solutions and setting strategic goals that reflect the complexity of opinions and options.

Due to the lack of identification of the second group with the information policy and its image dimension, civil society organizations focus primarily on the implementation of their vision of the national identity of Belarus within the state. In the first instance we are talking about initiatives and undertakings forming an ethnographic and cultural identity. An example of such initiatives could be the initiative of 'Mova nanova' ( Belarussian: Мова нанова, lit.: 'language anew'), an initiative which, thanks its increasing popularity, has turned into a registered organization - 'Socio-cultural institution for the development of the Belarusian language and culture Mova Nanova'12. This organization's activity consists of organizing publicly-available lessons of the Belarusian language (including for children), conducted in an interactive way, as well as other events promoting the Belarusian language in various cities of Belarus. Also, among other forms of activity forming the national identity and promoting Belarus in the context of its culture and national heritage, one can mention: the organization of tourist trips in Belarus; the promotion of Belarusian-language musical bands; and the promotion of Belarusian literature, cultural and linguistic traditions, and other aspects.

The social cultural campaign 'Let's be Belarusians!' (Будзьма беларусамі!), aimed at the development of Belarusian society based on national values and the formation of an attitude of respect for the Belarusian culture, has been operating since 2008 on the initiative of the international civic association 'Association of Belarussians of the world Fatherland'. Among the projects of this movement are: the annual Belarusian advertising and communication festival 'However!' (Аднак!); a series of hiking films 'Country | ВY' (Край | BY); a communication program 'Country of dragons' (Краіна цмокаў), presenting the dragon as a new alternative symbol of Belarus, as well

12 For more information, see http://www.movananova.by/ (accessed January 2016). 
as other events ${ }^{13}$. Although the campaign does not set for itself the task of forming the image of Belarus abroad, some of its materials are available in other languages (the text of the promotional cartoon entitled 'Let's be Belarusians!' is available in English, Polish, and Slovenian) ${ }^{14}$.

The social initiative 'Quote yours!' (Цытуй сваё!) can also be distinguished, as a result of which a collection of quotes by famous Belarusian activists and writers will be released ${ }^{15}$. The aim of this initiative is to show the specificity of Belarusian thought as a point of reference for defining individual worldviews and its way of functioning in the world in the Belarusian cultural context.

Independent Belarusian organizations and research centres also have an impact on the perception of Belarus through their preparation of independent analyses, studies, and expertise on, inter alia, the legal issues surrounding the functioning of media, forming an identity, foreign policy, and the competitiveness of Belarus on the international scene (the organizations that prepare materials also do so in English and / or other foreign languages). Such activities are carried out by the Belarusian Institute for Strategic Research ${ }^{16}$ (an external political index, studies on the international relations of Belarus, and a political media-barometer); the International Consortium EuroBelarus ${ }^{17}$ (strengthening and developing public and cultural policy, the development of communication space as a platform for dialogue on the topic of the Belarus-European relations); the project 'Belarus, image of the future'; the Ostrogorski

13 For more information, see http://budzma.by/about (10.01.2016) (Accessed January 2016).

14 For more information, see http://budzma.org/uncategorized/inna-historia-biaorusi.html (accessed January 2016).

15 For more information, see http://eurobelarus.info/special-project/god-belaruskaga-myslennya/2016/o1/og/tatstsyana-vadalazhskaya-belaruskae-myslenne-znahodz-ts-vodguk.html (accessed January 2016).

16 For more information, see http://belinstitute.eu/en (10.01.2016) (accessed January 2016).

17 For more information, see http://eurobelarus.info/consortium (10.01.2016) (accessed January 2016). 
Centr $^{18}$ (analysis of the transformation processes in Belarus on the way to transition to a market economy and the rule of law); the Belarusian Economic Research and Outreach Center BEROC ${ }^{19}$ (research into the field of the economy and educational programs, strengthening contacts with international academia); as well as others.

The most difficult issue for this group of institutions is, for the reasons already mentioned, to influence the formation of image communication. However, an attempt is being made to form an alternative image of Belarus through initiatives directly targeted at this goal. In 2015 The Movement 'For Freedom' organized a Summer School dedicated to the topic of the development of a national brand for Belarus. According to the organizers of the project, it provided a space for creation of an alternative to the officially promoted brand of the country, through meetings and discussions with well-known activists and experts on the subject ${ }^{20}$.

In this second group of institutions, independent media have the greatest potential for forming the image of Belarus in international communications. However, not all of them provide information in a language other than Belarusian or Russian. In addition, legal changes are tightening the working conditions of the independent media and reducing the activities of most of them to a completely illegal situation, which makes it impossible to build any positive dialogue between the authorities and civil society in the state, thus leading to an increased gap between the images built by these actors, which in turn negatively affects Belarus's position in international communications and blocks the implementation of most of the policy objectives of the independent media.

18 For more information, see http://ostrogorski.org (10.01.2016) (accessed January 2016).

19 For more information, see http://eng.beroc.by (10.01.2016) (accessed January 2016).

20 For more information, see http://pyx.by/bel/news/4428 (accessed January 2016). 


\section{Conclusions}

The Republic of Belarus, as a relatively young state, is in the process of seeking answers to the question of how to form its image on the international arena. Currently, it is based primarily on its national interests as consolidated in legal acts and state documentation. Analysis of the three key components - the identity of the state, legal regulations, and information policy - allows us to assess the prospects for forming the state's image in international communications.

The analysis shows that Belarus, as a state, uses political mechanisms that primarily serve to exert influence through information, in order to form an image consistent with the ideological principles of the state authorities. Not surprisingly, in this case the state ideology is a strong means of legitimizing the authorities, and a way to build the legal bases as well as formulate policy in the area of information and communication which aims to protect this national narrative against civic criticism from within the country, as well as by the international community. International communication and global information flows are perceived as a threat to national security and are considered in terms of an 'information war'. In this respect Belarus belongs to the group of non-democratic states, ensuring that the power of state authorities and their decisions are not subject to external challenges. The strict control over state power also prevents the natural unhampered formation of a national identity, instead reducing it to ideological slogans that do not have any real support among the citizens' convictions and experiences. Ideology, in the context of the strict state control over its implementation and the vertical structure of state administration, does not work in the face of changes occurring in international communication and lose their authenticity.

All these factors reduce the formulation of the state's image to propaganda activities that do not fit into the contemporary concepts of international communication. However, neither the official project for forming the image of the state on the international arena, nor the social alternative to do the same can be wholesome and productive 
in the present socio-political conditions. Without conducting an open dialogue and wide public consultations in this area, it is not possible to project a consistent image of Belarus in international communications.

\section{References}

Akudovich, V. (2007). Kod adsutnastsi (asnovy belaruskaĭ mentalnastsi). Minsk: Lohvinaŭ.

Akudovich, V. (2004). Razburyts' Paryzh. Minsk: Lohvinaŭ.

Aleksandrovich, Ia.M. (ed.) (2004). Natsional'naia strategiia ustoichivogo sotsial'no-ekonomicheskogo razvitiia Respubliki Belarus' na period do 2020 g. Minsk: Natsional'naia komissiia po ustoichivomu razvitiiu Respubliki Belarus', Iunipak, available at http://un.by/pdf/OON_sMall_Rus.pdf (accessed December 2015).

Babkoŭ, I. (2005). 'Henéaliohiia belaruskaŭ idèi', ARCHE, 3, 136-165.

Babkoŭ, I. (2003). 'Étyka pamezhzha: transkulturnasts' iak belaruski dosved', in Antsipenka A., Akudovich V. (eds.) Antaliohiia suchasnaha belaruskaha myslennia. Saint Petersburg: Nevskii prostor, 64-77.

Batalko, T.I., Pashkevich L.F. (2009). Osnovy ideologii belorusskogo gosudarstva. Vitebsk: Vitebskii Gosudarstvennyi Tekhnologicheskii Universitet.

Bulgakov, V. (2006). Istoriia belorusskogo natsionalizma. Vilnius: Institut belorusistiki.

Bulgakov, V. eds. (2006). Belarus': ni Evropa, ni Rossiia. Mneniia belorusskikh elit. Warsaw: ARCHE.

Bulhakaŭ, V. (2003). 'Moĭ Bahushèvich', in Antsipenka A., Akudovich V. (eds.) Antaliohiia suchasnaha belaruskaha myslennia. Saint Petersburg: Nevskii prostor, 328-351.

Dashkevich, V.O. ed. (2014). Mediasfera Belarusi. Sotsiologicheskii aspekt. Minsk: Informatsionno-analiticheskii tsentr pri Administratsii Prezidenta Respubliki Belarus', p. 16, available at: http://iac.gov.by/sbornik/Mediasfera_Belarusi.pdf (accessed: December 2015).

Ekadumov, A. (1999). 'Bezdomnaia natsiia evropeiskogo doma', ARCHE, 1, 199-204.

Gorskii, I.N. (2010). 'Vneshnii imidzh gosudarstva: informatsionno-semioticheskii aspekt', Vesti Instituta sovremennykh znanii, 3, 90-94. 
Iankovskaia, L.V. (2009). Osnovy ideologii belorusskogo gosudarstva. Novopolotsk: Polotskii gosudarstvennyi universitet.

Kazakevich, A. (2010). 'Kantsèptsyi (idèi) belaruskaŭ natsyi ŭ peryiad nezalezhnastsi, 1990-2009', Palitychnaia sfera, 14, 21-40.

Kazakevich, A. (2004). 'Belaruskaia sistema: marfalohiia, fiziialohiia, henealogiia', ARCHE, 4, 51-84.

Kniazev, S.N., Reshetnikov, S.V. eds. (2004). Osnovy ideologii belorusskogo gosudarstva. Minsk: Akademiia upravleniia pri Prezidente Respubliki Belarus'.

Naumenko, L.I. (2012). Belorusskaia identichnost'. Soderzhanie. Dinamika. Sotsial'no-demograficheskaia i regional'naia spetsifika. Minsk: Belaruskaia dumka.

Naumenko, L.I. (2008). 'Etnicheskaia identichnost' belorusov: soderzhanie, dinamika, regional'naia i sotsial'no-demograficheskaia spetsifika', in O.V. Proleskovskii, G.V. Osipova (eds.), Belarus' i Rossiia: sotsial'naia sfera i sotsiokul'turnaia dinamika. Minsk: IATs, 111-133.

Nikitenko, P.G. ed. (2009). Filosofiia i ideologiia zhiznedeiatel'nosti Belarusi. Minsk: Natsional'naia Akademiia Nauk Belarusi, Belaruskaia navuka.

Prokopiuk, J. (2013). Etnos i tożsamość. Białoruski proces narodotwórczy. Toruń: Tako, $118-127$.

Radio Svoboda - news service (2018). Popravki v zakon o SMI v Belorussii vyzvali kritiku, 14 June, available at https://www.svoboda.org/a/29291009. html (accessed August 2018).

Rubinov, A. (2006). 'Eshche raz ob ideologii', Sovetskaia Belorussiia, 29 December, available at http://www.sb.by/politika/article/eshche-raz-ob-ideologii.html (accessed January 2016).

Rudkouski, P. (2017). Soft Belarusianisation. The ideology of Belarus in the era of the Russian-Ukrainian conflict, 'OSW Commentary', 253, available at https://www.osw.waw.pl/sites/default/files/commentary_253-tv.pdf (accessed August 2018).

Rudkoŭski, P. (2006). 'Ad identychnastsi da sabornastsi', ARCHE, 1-2, 62-68.

Rudkoŭski, P. (2006). Paŭstan'ne Belarusi. Vilnius: Instytut belarusistyki.

Shestakova, O. (2009). 'Belorusy schitaiut glavnym pisatelem Iakuba Kolasa, a deiatelem - Frantsiska Skorinu', Komsomol'skaia pravda v Belarusi. 9 November, available at http://www.kp.by/daily/24390.5/569426/ (accessed January 2016). 
Shraibman, A. (2017). Fenomen belorusskoi gosudarstvennosti. Chto zhdet sistemu Lukashenko. Moscow: Moskovskii Tsentr Karnegi.

Tut.by - news service (2018). Izmeneniia v zakon o SMI: Kommentatorov v internete predlagaiut identifitsirovat'. Kak — reshit Sovmin, 2 April, available at https://news.tut.by/society/587348.html (accessed August 2018).

Usow, P. (2016). 'Białoruś - „neoautorytaryzm z ludzką twarzą??', Wschód Europy • Vostok Evropy • East of Europe, 2:2, 13-28.

Vodolazhskaia, T. (2010). K postanovke problemy belaruskoi identichnosti available at http://methodology.by/?p=693 (accessed: January 2016).

Main legal texts, reports and programs examined

Act of 14 June 2018 'On introducing changes and amendments to some laws of the Republic of Belarus', available at http://www.house.gov.by/ru/zakonyru/view/o-vnesenii-izmenenij-i-dopolnenij-v-nekotorye-zakony-respubliki-belarus-437/ (accessed August 2018).

Constitution of the Republic of Belarus of 1994 (with changes and additions, adopted in national referenda on 24 November 1996 and 17 October 2004), available at http://www.pravo.by/main.aspx?guid=6351 (accessed December 2015).

Decree of the President of the Republic of Belarus of 9 November 2010 No. 575 'On approval of the National Security Concept of the Republic of Belarus' (with changes and additions, adopted on 30 December 2011 No. 621 and on 24 January 2014 No. 49), available at http://www.pravo.by/world_of_law/ text.asp?RN=P31000575 (accessed December 2015).

Freedom House (2017), Report 'Freedom on the Net 2017', available at https:// freedomhouse.org/report/table-country-scores-fotn-2017 (accessed August 2018).

Law of 14 November 2005 No. 6o-3 'About approval of the main directions of domestic and foreign policy of the Republic of Belarus', available at http://pravo. by/document/?guid=3871\&po=h10500060 (accessed August 2018).

Law of 17 July 2008 No. $427-3$ 'On mass media', available at http://www.pravo. by/main.aspx? guid $=3871 \& \mathrm{po}=\mathrm{H} 10800427$ (accessed December 2015).

Law of 10 November 2008 No 455-3 'On Information, Informatization and Protection of Information', available at http://www.pravo.by/main.aspx?guid $=3871 \& \mathrm{po}=\mathrm{h} 10800455 \& \mathrm{p} 2=\{\mathrm{NRPA}\}$ (Accessed December 2015).

Lawtrend (2015). The results of a public opinion poll on the relevance of the problems of the 'free Internet', available at http://www.lawtrend. 
org/information-access/rezultaty-oprosa-obshhestvennogo-mneniya-natemu-aktualnosti-problematiki-svobodnogo-interneta (accessed December 2015).

Natsional'nyi doklad k universal'nomu periodicheskomu obzoru (vtoroi tsikl), Respublika Belarus' (2015), Minsk, available at http://mfa.gov.by/upload/ UPR_Belarus_National_Report.pdf (Accessed December 2015).

OSCE Office for Democratic Institutions and Human Rights (2015). Interim report of Election Observation Mission on the Presidential Election, 11 October 2015, in the Republic of Belarus, available at: https://www.osce.org/ odihr/elections/belarus/183996?download=true (accessed January 2016).

Report of the UN Special Rapporteur on the situation of human rights in Belarus (2015) A/70/313, Seventieth session, Item 73 (c) of the provisional agenda: Promotion and protection of human rights: human rights situations and reports of special rapporteurs and representatives, available at http://www.un.org/ga/search/view_doc.asp?symbol=A/70/313\&referer=/ english/\&Lang=E (accessed December 2015).

The Decision of the Council of Ministers of the Republic of Belarus of 26 October 2001 No. 1545 'On approval of the Regulations on the Ministry of Information of the Republic of Belarus', available at http://www.pravo.by/main. aspx?guid $=3871 \& p o=C 20101545$ (accessed January 2016).

The Decision of the Council of Ministers of the Republic of Belarus of 30 October 2001 No. 1558 'Questions of the Ministry of Culture of the Republic of Belarus', available at http://www.pravo.by/main.aspx?guid $=3871 \& \mathrm{po}=\mathrm{C} 20101558$ (accessed January 2016).

The Decision of the Council of Ministers of the Republic of Belarus of 29 June 2006 No. 963 'Questions of the Ministry of Sport and Tourism of the Republic of Belarus', available at http://www.pravo.by/main.aspx?guid $=3871 \& \mathrm{po}=\mathrm{C} 20600963$ (accessed January 2016).

The Decision of the Council of Ministers of the Republic of Belarus of 31 June 2006 No. 878 'Questions of the Ministry of Foreign Affairs of the Republic of Belarus', available at http://www.pravo.by/document/?guid $=3871 \& \mathrm{po}=\mathrm{c} 20600978$ (accessed January 2016).

The Decision of the Council of Ministers of the Republic of Belarus of 26 December 2010 No. 1905 'On approval of the State program 'Culture of Belarus' for 2011-2015', available at http://www.pravo.by/pdf/2011-11/2011-11(029-091). pdf (accessed January 2016). 
The Ministry of Foreign Affairs of the Republic of Belarus. Priorities of the foreign policy of the Republic of Belarus, available at http://mfa.gov.by/en/ foreign_policy/priorities/ (accessed January 2016).

The Ministry of Sport and Tourism of the Republic of Belarus. State program for the development of physical culture and sports in the Republic of Belarus for 2011-2015, available at http://mst.gov.by/ru/razvitie-sporta (accessed January 2016).

2018 World Press Freedom Index, available at https://rsf.org/en/ranking. (accessed August 2018).

Dr Elena Zhminko is a specialist in public and cultural diplomacy and is based in Brest, Belarus. Being associated with both the University of Warsaw (Poland) and Brest State University (Belarus), she has published several articles on the topics of international communication, cultural diversity, and the identification of national minorities. As a project manager, trainer and evaluator, she has supported democratization programmes in Eastern Europe and the Caucasus. She is currently working in the Consulate General of the Republic of Poland in Brest.

\section{Elena Zhminko}

